\title{
Magyar utazók japán fotográfiái mint gyermekkortörténeti dokumentumok
}

Adalékok a japán gyermekkortörténethez

\section{HÁRSVÖLGYI VIRÁG}

ELTE PPK Neveléstudományi Doktori Iskola

\begin{abstract}
A tanulmány kiindulópontját két magyar utazó fotográfiai anyaga jelenti. A múzeumalapító, világutazó Hopp Ferenc (1833-1919) és a sorhajóorvosként múködő dr. Bozóky Dezső (1871-1957) bár amatôr fényképészek voltak, mégis a magyar fotográfia történetének meghatározó alakjaiként ismertek. Japánban tett utazásaiknak emlékét a szöveges dokumentumok mellett unikális képi anyag őrzi. A gyújteményükben megőrződött felvételek közül most a japán gyermekeket megjelenítő fotográfiák állnak az érdeklődés fókuszában. Ezek a felvételek mára kordokumentumnak számítanak, különösen értékesek a történeti kutatás számára, elemzésük kvázi szövegként járulhat hozzá a japán gyermekkép kutatásához.
\end{abstract}

Kucsszavak: gyemekkor, Japán, fotográfiák

\section{BEVEZETÉs}

Japán magyarországi recepciótörténetének vizsgálatakor a szöveges dokumentumok mellett fontos szerephez jutnak a vizuális források is. Magyarországon az első, Japánnal kapcsolatos értesülések közvetítő nyelvekből származtak, eleinte többszörös szûrû́n keresztül ültették át azokat magyar nyelvre (Buda, 2010. 17. o.), így a korai szövegek tanulmányozásakor érdemes körültekintően eljárni. Az ismeretek terjesztéséhez azonban nemcsak az írott anyagok, hanem a képek is nagymértékben hozzájárultak, különösen onnantól kezdve, hogy az új képrögzítési eljárás, a fotográfia ezt lehetővé tette.

Jelen tanulmány szempontjából kiemelten fontosak azok a 19. század végi, 20. század eleji képi dokumentumok, melyek magyar személyekhez kötődnek. Köztük a múzeumalapító, múgyuujtő, világutazó Hopp Ferenc (1833-1919) és a sorhajóorvosként szolgálatot teljesítő dr. Bozóky Dezső (1871-1957) a magyar fotográfia történetének meghatározó alakjaiként ismertek, annak ellenére, hogy egyikük sem volt hivatásos fotográfus. Fényképészeti, gyứjtői munkásságuk, kultúraközvetítő tevékenységük mégis a történeti kutatás homlokterében helyezi el mindkettejüket. 
Hopp Ferenc, aki szakmáját tekintve optikus volt, a főváros hosszú időn át legjobbnak számító fényképészeti szaküzletében, a Calderoni István-féle Calderoni optikai cégnél kezdetben optikusinasként tevékenykedett, később a vezetését is átvette (Ferenczy, 2008. 31. o.). Amikor anyagi helyzete már lehetóvé tette, európai utakon kívül világkörüli utazásokra is vállalkozott - Japánban három alkalommal járt: 1883-ban, 1903-ban és 1914-ben -, mely utak során a jó szemú optikus maga is számos felvételt készített, azokkal több kiállításon szerepelt és vetített képes előadásokat is tartott, például a Magyar Földrajzi Társaság összejövetelein (Ferenczy, 2008. 37. o.). Saját képei mellé kiegészítésül, valamint úti emlék gyanánt mások által készített, albumba rendezhető fotográfiákat is vásárolt; ezek olyan jeleneteket, helyzeteket ábrázoltak, amik felkeltették az érdeklődését - például múemlékek, tájak, helyi viseletek iránt -, illetve amiknek ő maga nem lehetett szemtanúja - mint például bizonyos ünnepek, szokások, intimebb jelenetek (Ferenczy és Kincses, 1999. 57. o.).

Dr. Bozóky Dezső mint császári és királyi sorhajóorvos az Osztrák-Magyar Monarchia haditengerészetének kötelékében 1908 és 1909 között két éven át hajózott kelet-ázsiai vizeken (Fajcsák, 2009. 130. o.). 1911-ben Két év Keletázsiában címmel, két kötetben foglalta össze útirajzait: az első kötetben Kína és Korea, míg a második kötetben Japán kapott helyet, ez utóbbi több mint ötszáz oldalon. A tizenhét fejezetet háromszáz képpel illusztráló kötet az egyik legfontosabb japán vonatkozású könyv a 20. század elejéről Magyarországon, benne számos, a kutatás számára releváns szöveges és vizuális információval. Bozóky ugyancsak vásárolt képekkel egészítette ki saját készítésú fotográfiai anyagát, melyeket tematikus albumokba rendezve a közvetlen nézegetésre, míg egyéb felvételeit publikus vetítésre szánta.

Hopp Ferenc és Bozóky Dezső felvételei - legyenek azok saját kezúleg készítettek vagy vásároltak -, mára kordokumentumnak számítanak, gyújteményükben megőrződött képeik közül most a japán gyermekeket megjelenítő, válogatott fotográfiák állnak az érdeklődés fókuszában.

Tekintettel a jelen tanulmány terjedelmi korlátaira, a vizsgálat tárgyát most mindössze néhány kép alkotja, melyek különösen értékesek a kutatás számára mint a gyermekekkel való bánásmód tükrözői. Elemzésük alapján a japán gyermek környezetének történeti távlatú rekonstrukciójára is vállalkozhatunk, amely - látni fogjuk - egészen a játékszertörténetig ível, illetve a japán játék hazai, közgyújteményi jelenléte okán kiemelt hangsúlyt is kap.

\section{A JAPÁN GYERMEKKORTÖRTÉNET VIZUÁLIS LENYOMATAI - AZ ANYASÁG KÉPEI}

Hopp Ferenc az első földkörüli útjáról, mely Japánt is érintette (1883), a kutatás számára nézve is értékes fotóalbum maradt fenn a Hopp Ferenc Ázsiai Müvészeti Múzeum (továbbiakban Múzeum) gyújteményében. Ebből az albumból most két 
olyan, kézzel színezett felvétel képezi az elemzés tárgyát, melyek az anyaság képeiként határozhatók meg.

A két fotográfia a fotóalbumban nem egymás mellett kapott helyet, mégis egy előtte-utána jelenetként értelmezhetőek leginkább. ${ }^{1}$ Az egyik felvételen egy édesanyát/dajkát látunk, aki éppen csecsemőt táplál (1. kép).

A jelenet bal oldalán kissé elmosódott, de fontos képi elem egy kölyökkutya. Jelenléte a felvételen nem véletlenszerú, alakja szimbolikus tartalom hordozója, ennek okán kerülhetett a képre. Egy japán kisgyermek hagyományosan az első születésnapkor ${ }^{2}$ kapta meg első játékszereit: köztük a babát és a kutyát mintázó figurát (Frédéric, 1974. 32. o.). Ez utóbbi amulett és játéktárgy is volt egyben, hiszen a kutyákról - védelmező, őrző tulajdonságaik okán - úgy tartották, hogy

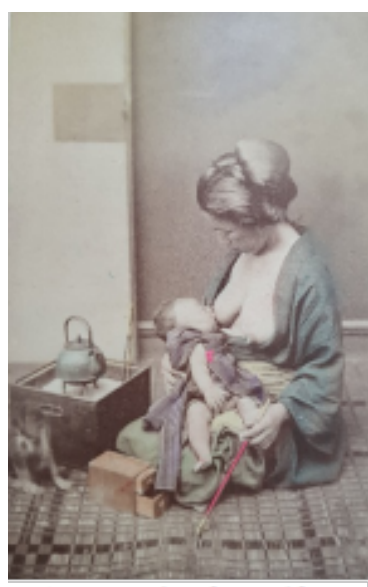

1. Ismeretlen fotográfus: Szoptatás

kézzel szinezett fénykép, 1880 körūl

Hopp Ferenc albumából Ltsz: 82.3 képesek felismerni az emberi alakot öltött démonokat, így hagyományosan a kisgyermekek védelmezőiként múködtek. Az újszülöttek első, sintó szentélybeli látogatásukkor kapták a figurákat, hogy megvédjék a gyermeket a betegségektől, és távol tartsák a gonosz erőket. ${ }^{3-4}$

\footnotetext{
${ }^{1}$ A Múzeum japán anyagát feldolgozó projekt keretében elkészült katalógusban a két fotográfia képe már egymás mellett jelent meg (Japanese Art Abroad Research Project, 1995. 258. o.). A kutatók felismerték a képek összetartozását, melyek így már koherens egységként kezelhetőek.

${ }^{2}$ Egy ember életideje már a fogantatás pillanatától számított, így a japán gyermek születésekor tulajdonképpen már egyéves volt (Frédéric, 1974. 32. o.). „A felnövekvő ember az idó észlelését - miként minden egyéb tudását - a számára adott kultúrába betagolódva sajátítja el, így az időhöz is kultúrájának szabályai szerint viszonyul." (Németh, 2011.7. o.)

${ }^{3} \mathrm{~A}$ hagyományos japán társadalomban az újszülött első fürdetését szertartásszámba menő elemek szőtték át, különösen arisztokrata körökben. A baba fürdővízébe ékszereket tettek, a víz fölé pedig kutya vagy tigris képét tartották, hogy a szimbolikus védőerőt képviselő alakok visszatükröződjenek benne, így oltalmazva a gyermeket (Frédéric, 1974. 27. o.). A kutya jelenléte az ábrázolásokon élőlényként vagy játéktárgyként - egyaránt fontos, és szimbolikus jelentése akkor sem veszít erejéből, ha nagyobb gyermekek vagy akár felnőtt hölgyek környezetében látjuk. E tekintetben is érdemes az archív fotókat vizsgálnunk.

${ }^{4}$ Napjaink Japánjában a kutya figurája egy sokkal hétköznapibb módon, de a szimbolikus erejébe vetett hitet megőrizve kap helyet a várandós édesanyák számára megvásárolható, pocakra köthető bandázsban (haramaki). A várandósság ötödik hónapjában, a kutya napján tartott rituális alkalomkor (Inu-no-hi) kerül sor az obi-ivai-ra, azaz ekkor kötik fel rituálisan a pamutszárnyakat a várandós
} 
Egy ugyancsak jellegzetes tárgy, ami a kisgyermek születésétől fogva része a játéktárgyi környezetnek, az a fent említett játék baba, amely a vizsgálat tárgyát jelentő, következő fotográfián is jól kivehető (2. kép).

Ezen a felvételen a csecsemő - ta-

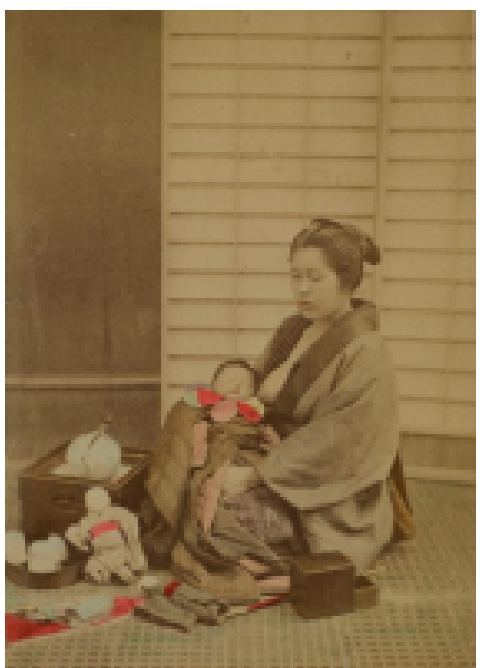

2. Ismeretlen fotográfus: Dajkálás

kézzel szinezett fénykép, 1880 körūl

Hopp Ferenc albumából Ltsz.: 82.3 lán éppen a korábbi jelenet folytatásaként - már jóllakottan szundít édesanyja/dajkája karján, gondosan bebugyolálva. A jelenetben feltúnő elem a szituációhoz hozzá tartozó, földön heverő, két icsimacu baba. Mielőtt rátérnénk a konkrét játék baba jelentésrétegeinek bővebb ismertetésére, érdemes további vizuális hordozókat is bevonni a vizsgálat körébe. A fotográfiákon kívül a japán fametszetes ábrázolások ugyancsak alkalmasak az anyaság képeinek tanulmányozására, és a fotográfiákkal szépen párhuzamba állíthatók, sőt, a fényképezés feltalálása előtti időkből a fametszetek ábrázolásai nyújthatnak fogódzókat a kutatás számára. ${ }^{5}$

Az anyaság témája külön egységet alkot a fametszeteken belül, ahol bosi-e néven foglalják össze az anyákat gyermekükkel ábrázoló nyomatokat. ${ }^{6}$

Ezek az intimitást sugalló képek bensőséges anya-gyermek viszonyról tanúskodnak, a megfigyelt jelenetekben hétköznapi szituációkat látunk: az anyát, aki gyermekét táplálja, gondozza, dédelgeti, játszik vele, közben pedig az emberi élet mérföldköveinek számító gyermeki ünnepekbe, azok szokásaiba is betekintést nyerünk. A Múzeum japán gyújteményében több olyan fametszet is található, melyek az említett képtípust reprezentálják, közülük Kitagava Utamaro I (1753-1806) „Anya gyermekkel” címú fametszete a típus egyik szép példája (3. kép).

édesanya hasára (Papp, 2013. 238. o.).

5 A hagyományos japán esztétikai rangsorban az írás és a festészet vezető szerepet töltött be. Eszközei is megegyeztek (ecset, papír, tus, tusdörzsölő). Ez azt is jelenti, hogy amikor szövegekhez fordulunk, akkor egyúttal a képekhez is fordulunk, illetve szöveg hiányában megbízható forrásaink lehetnek a képek, hogyha történeti távlatokban a mindennapi életet szeretnénk tanulmányozni (Frédéric, 1974. 11. o.).

62017 tavaszán a krakkói Nemzeti Múzeum rendezett a japán társadalom női szerepeire reflektáló kiállítást Onna címmel, amiben külön egységet alkotott az anyaság (bosi-e) témáját bemutató fametszetek sora (Romanowicz, 2017. 54-65. o.). 
Az édesanya, nyitott keble fölött, karjában tartja gyermekét, aki látszólag már igen türelmetlen, akaratának ökölbe szorított kezével ad nyomatékot, közben a jelenet másik hölgye (dajka?) talán éppen azt ellenőrzi, hogy van-e elég anyatej, hogy a gyermek éhségét csillapítsák. A japán nyelv érdekessége, hogy a nő (女, onna) és a gyermek (子, ko) jelentésú karakterek együttes értelme: valakit vagy valamit kedvelni, szeretni (好). ${ }^{7}$ A szóösszetétel már önmagában is hordozza azt a feltétel nélküli szeretetviszonyt, ami az említett képeknek sajátja.

\section{JAPÁN GYERMEK - JAPÁN BABA}

Hagyományosan a japán kisgyermeknek egy hónapos koráig az édesany-

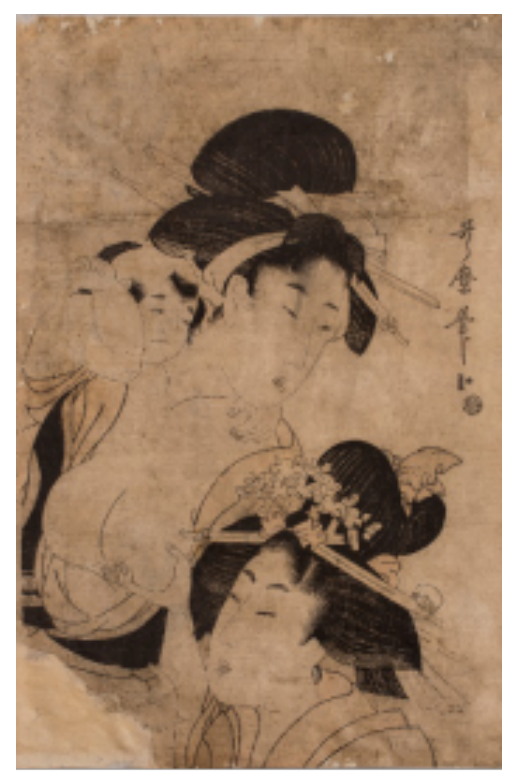

3. Kitagava Utamaro I: Anya gyemekkel szines fametszet, 1804-6 Ltsz: 6512 ja karján volt a helye, majd onnantól kezdve az anya hátán hordta a babát (Frédéric, 1974. 30-31. o.) a mindennapi tevékenységek végzése közben. (4-5. kép)

Ez igaz volt a nagyobb testvérekre is, akik ugyancsak hátukra vették a kistestvért, még játék - például szaladgálás, de még ugróiskolázás - közben is (Benedict, 1954. 257. о.).

Ebben a testhelyzetben a baba „megtanul egy kismacskához hasonlóan hozzásimulni bárkinek a hátához, aki viszi. [...] a baba saját erőfeszítésein múlik, hogy kényelmes helyzetet biztosítson magának és hamarosan megtanulja, hogy figyelemreméltó ügyességgel utazzon hordozóján ahelyett, hogy csak egy vállra kötözött csomag legyen." (Bacon, 1891. 10. o.).

Bozóky Dezső említett útleírását olvasva rájövünk, hogy alaposan szemügyre vette az általa „,ici-pici kedves népség"-nek nevezett japán gyerekek megjelenését, játékait, ünnepeit, a nagyobbak viszonyát a kisebbekhez stb. Az útikönyvében közölt egyik fotó ${ }^{8}$ alá (6. kép) a következő sorokat írta: „minden gyermek hátán lovagol egy gyermek" (Bozóky, 1911. 208. o.).

\footnotetext{
${ }^{7}$ Lázár Marianna szíves közlése.

${ }^{8}$ A fotó nem Bozóky saját felvétele, japán útja során vásárolhatta. Ezt erősíteni látszik az a tény, hogy ugyanennek a gyerekcsoportnak a képét egy japán nyelvû könyv is közli (Shimokava, 2002. 288. o.).
} 

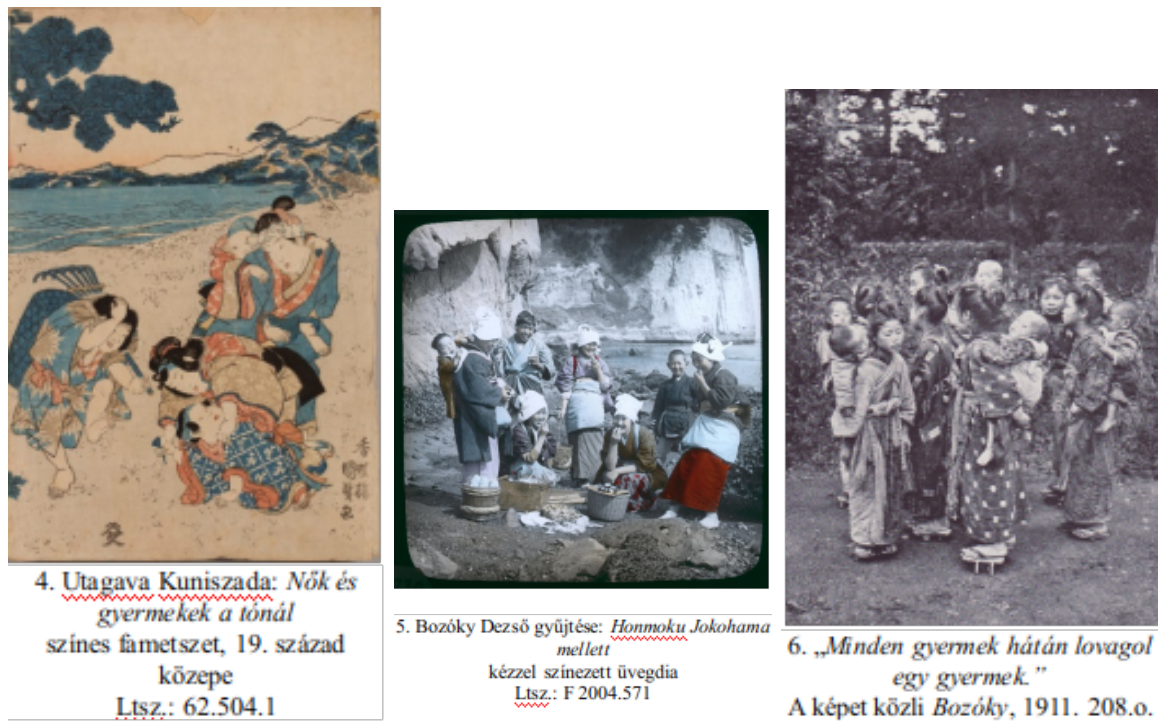

A jelenet a szabad levegőn összeverődött gyerekek - vélhetően komorik ${ }^{9}$ csoportját ábrázolja. A felvétel érdekessége, hogy a kislányok mindegyike egy kisbabát cipel a hátán. És noha Bozóky külön nem említi, orvosként valószínúleg maga is megállapíthatta, hogy komoly tehertétel egy gyermek gerincének, ha egy másik kis testet hordoz a hátára kötve.

Minden bizonnyal nem volt előzmények nélküli a testhasználat eme formája, amit viszont megerősít a hajóorvos leírása, aki a következő megállapítást tette: „[...] minden kis leány, amelyik még nem tud igazi babát hordani a hátán, ilyen kis babát visel egész nap a hátán." (Bozóky, 1911. 25. o.)

Ez a megjegyzés igen fontos a tárgyalt téma szempontjából, hiszen itt már a játékszer irányába is kitekintést nyújt a képelemzés. Bozóky ugyanis a "kis baba" meghatározás alatt a

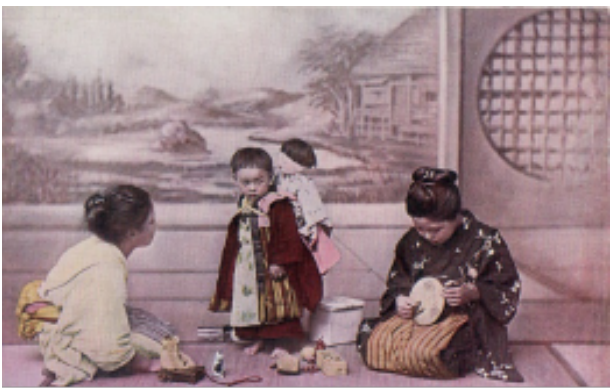

7. Japán kisgyermek hátán cipeli az icsimacu babát fotográfiai képeslap, 1900 kôrül (a szerzô tulajdona) valódi kisgyermeket mintázó icsimacu babát értette, amit apró tulajdonosaik ugyanígy a hátukon cipeltek, mint ahogyan a felnőttek a kigyermekeket, így ez a gesztusrendszer beépült a testükbe (7. kép).

A kislányok - a majdani családanyai szerepre való felkészülést is elősegítendő

\footnotetext{
${ }^{9}$ A komori kifejezés egy szóösszetétel, és olyan személyeket jelöltek ezzel a szóval, akik gyermekről gondoskodtak. Köztük gyermekek is voltak, akiket gyermekgondozásra szoruló családok alkalmaztak. Kardos Tatjána szíves közlése.
} 
- a "gyakorlati cselekvés képeit, sémáit, mozgásait”, a „helyes felnőtt eljárást” tanulták meg a mimetikus folyamatokban (Hearn, 2009. 216-217. o.; Wulf, 2007. 181. o.; Benedict, 1954. 266. o.).

Nem lehet véletlen, hogy nem is játéknak túnnek ezek a babák, mint ahogy az sem lehet csupán a japán esztétikai elvárásnak való megfelelés, hogy szép legyen a baba. Nagyon úgy túnik, hogy egy ilyen élethú, törékeny babával tanulták meg a kicsi japán gyerekek, hogy egy valódi kisbabával hogyan tudnak majd helyesen bánni, vele együtt játszani, ily módon a játék baba nevelési-oktatási szerepet is betöltött.

\section{Icsimacu baba - kvázi gyermek}

Általános értelemben vett nyugati fogalmaink szerint a $b a b a$ kisméretú emberi figura, gyakran csecsemő ${ }^{10}$ vagy kislányforma, gyermekjáték, mellyel játszani lehet, babusgatni és számos formában manipulálni. Alapvetően nem volt ez másként a japán gyermekek babajátékainál sem: "A kisgyerekek a babákkal házvezetést, esküvőt vagy ünnepeket játszanak, miután alaposan megvitatták, hogy milyen a 'helyes' felnőtt eljárás [...]" (Benedict, 1954. 266. o.), és mindeközben leképezték azt a kommunikációs mintázatot, társadalmi szabályrendszert és szerepviszonyokat, amely körül vette őket, amelyben nevelkedtek.

A játék baba fent nevezett, általános meghatározása azonban nem fedi le teljesen a japán ningjó szó gazdag jelentésrétegeit és típusait. A ningjó szó jelentése emberi alak, emberi forma, illetve a kifejezés általánosságban kiterjed a kicsinyített figurákra, függetlenül attól, hogy azokat mire használták. A japán nyelv olyan tárgyakra is alkalmazza a babának megfeleltethetô ningjó megnevezést, amelyeket nyugati szóhasználatban nem neveznénk babának, hanem inkább dísztárgynak vagy ünnepi kelléknek.

Azonban a nyugati fogalmaink szerinti dísztárgy megnevezés nem a legmegfelelőbb a japán tárgyak meghatározását illetően, mert Japánban jellemzően minden tárgy használati tárgy. A dekoratív hajlam, az esztétikai igény és a funkcionalitás egymást nem kizáró tényezők, és ez egyaránt igaz egy teáscsészére, csakúgy, mint egy kardtartozékra vagy akár egy babára. A nyugati múvészetfelfogásban „amint egy eszköz a cél betöltése mellett esztétikai igényeket is kielégített, minden korban különös megbecsülésnek örvendett". ${ }^{11}$

Ez a hozzáállás lehet az egyik oka annak, hogy nyugati értelemben nem úgy tekintünk a japán babákra, mint a gyermek játéktevékenységében fontos szerepet betöltő játékszerekre, hanem mint „múalkotásra”. Azonban az icsimacu

\footnotetext{
${ }^{10}$ Hathalmi Gabnay Ferenc, az első hazai játékkutató, 1901-ben az alábbi babameghatározást adta: „[...] a babák [...] első sorban csak gyermekek, nevezetesen csecsemők utánzatai voltak, a melyeket az anyák készítettek gyermekeiknek, hogy azokkal játékképen úgy bánjanak el, mint a hogyan ök velük komolyan elbánnak [...]" (Hathalmi, 1901. 17. o.).

11 http: //arthist.elte.hu/TAMOP_412/1_1_einfuehrung.html\#idp1220496 (Hozzáférés ideje: 2017. február 8.)
} 
babák alapvetóen játékok voltak, megjelenésüket a 18. századi kabuki színész, Szanogava Icsimacu (1722-1763) inspirálta. A női (onnagata) szerepeket játszó férfi színész személye, illetve teljes megjelenése hamar az érdeklődés középpontjába került. Az arcvonásaival készített babák rövid időn belül nagy népszerûségre tettek szert, és a színész neve alapján kezdték el ôket icsimacu babáknak nevezni. Szanogava Icsimacu kora idolja volt, melyet kihasználtak a babakészítők, és elkészítették a celebritás babaképmását (Takeguchi, 2002. 50. o.).

A típus megalapozása a Taisó-korban (1912-1926) kezdődött, amikor a párban készített icsimacu babákat esküvői ajándékként adták a házasulandóknak, gyermekáldást kívánva velük. Egy másik típus elterjedtebb volt a korábbi Meidzsi-időszakban (1868-1912), ahol a fiatalabb gyermekeket, csecsemőket a nemük meghatározása nélkül, kopasz fejjel, hosszú gyermek-köntösben, partedlivel és sapkában jelenítették meg. Mindkét típus az icsimacu babák kategóriájába tartozik (Pate, 2000. 237-238. o.). Ezek a babák igényes kidolgozásuk okán, valósághú megmintázásukkal könnyen igazinak túnhettek, amit a fotográfusok ki is használtak.

A 19. század végétól tömegével készültek olyan fotók, illetve képeslapok, ahol nők karjára helyezett vagy japán módra háton cipelt "gyermekeket" látunk (Hearn, 2009. 217. o.). A kamera azonban nem tudja teljesen becsapni a nézőt, hiszen sokszor nem is valódi kisgyermekeket, hanem icsimacu babákat (8. kép) ölelnek, hordoznak a hölgyek.

A sokszorosító múfajban feltúnően sok példát láthatunk erre, gyújtés tárgyát is képezik az ilyen ábrázolások, ezért érdemes alaposabban is megvizsgálni a játék baba helyét és szerepét. Egyrészt nem volt szokatlan dolog a Meidzsi-korban, hogy a még férjezetlen, gyermektelen nók rendelkeztek icsimacu babával, hiszen a gyermekáldás kívánságának a gondolatköre is hozzátartozott a játék babákhoz

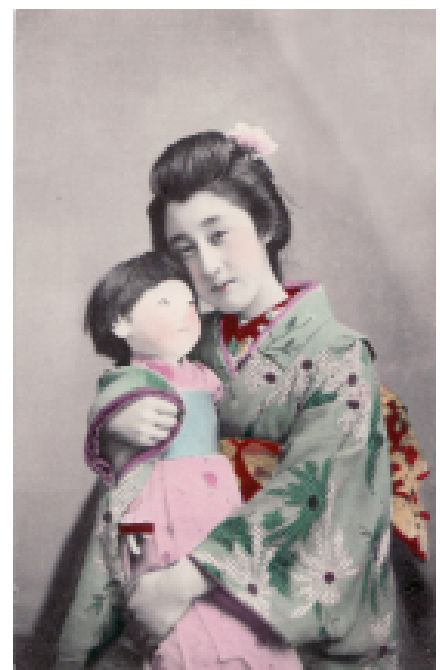

$$
\begin{aligned}
& \text { 8. Japán nö icsimacu } \\
& \text { babával }
\end{aligned}
$$

\section{fotográfiai képeslap, 1905} (Pate, 2000. 238. o.).

Ezeket a babákat úgy kezelték, mintha valódiak lennének, volt külön fekhelyük, váltás ruhájuk, etették-itatták őket, még nevet is kaptak. A lánybabákat O-toku-szannak, a fiúkat Tokutarószannak nevezték. Úgy hitték, ha elhanyagolják őket, akkor az embertelen 
bánásmód szerencsétlenséget hoz. Tehát a babákkal jól kellett bánni ahhoz, hogy szerencsét hozzanak a ház népére. Úgy tartották, hogy a baba teste képes (emberi) lélekkel megtelni, és természetfeletti erővel rendelkezik ${ }^{12}$, így például a gyermektelen párok is reménykedhettek gyermekáldásban, ha megfelelően gondoskodtak egy Tokutaró-szan babáról (Hearn, 2009. 217. o.; Davis, 1992. 214-216. o.). Emellett praktikus oka is volt a játék baba fotóalanyként történő alkalmazásának: könnyebb volt a kamera előtt megfelelően elrendezni, mint egy valódi kisbabát, és mivel a fotóstúdiók fizetett hölgyeket/modelleket foglalkoztattak nem civileket -, így a karjukon egyértelmúbb helye volt a játék babáknak, mint egy valódi gyermeknek. ${ }^{13}$

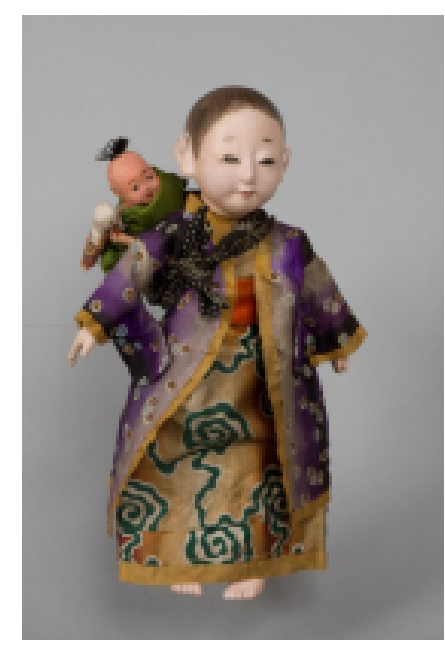

9. Icsimacu baba

Fa, gofun, üvegszemek, selyem, papir

1900 körül

Ltsz.: 58.9.1.1-2

Gyưjtéstörténeti érdekesség, hogy a Múzeum is őriz egy icsimacu babát, ami Kertész K. Róbert $^{14}$ gyújtéséből származik. Az építész 1904-ben, távol-keleti tanulmányútja során vásárolta a játékot (Hársvölgyi, 2018. 150. o.), és 1958-ban fia révén került a Múzeum tulajdonába. (9. kép)

A Múzeumban őrzött, ringatnivaló fiúcskababa feje sima, a leborotvált hajat festés érzékelteti, pufók, rózsaszínes arcocskája rendkívül finom vonásokat mintáz, üvegszemei élénken csillognak, hosszú köntöse selyemből van. A baba nem önállóan, hanem "babahármasságként" jelenik meg - a fó baba hátán hordoz egy kisebb babát, akinek szintén van egy játék babája -, szépen reagálva a már többször említett gyermekhordozási metódusra.

\section{A baba ereje}

A fentiek alapján nem kétséges, hogy a japán játék baba profán és szakrális funkciótartományokban is értelmezhető, akár gyermek, akár felnőtt társaságában találjuk. A képeken kívül egyes szövegek is segítenek megvilágítani a játék baba jelentőségteljes voltát. Szimbolikus erejét jól példázza egy szívmelengető esetnek a leírása, amit a magyar közönség fordításból ismerhetett

\footnotetext{
12 Egy legenda elbeszéli, hogy egy baba a tüzet fogott égő házból futva menekült biztonságos helyre (Davis, 1992. 215. o.).

${ }^{13}$ Kardos Tatjána szíves közlése.

14 Kertész Károly Róbert (1876-1951) építész, kultuszállamtitkár. 1904-ben a vallás- és közoktatásügyi és a kereskedelemügyi minisztérium támogatásával építészeti tanulmányokat folytatott Kelet-Ázsiában (Fajcsák, 2009. 167. o.).
} 
a 20. század elején Imaoka Dzsúicsiró ${ }^{15}$ tolmácsolásában. A történet Szaidzsó Jaszo gyermekmeseköltővel esett meg: a költő éppen európai útjára készülődött, amikor egy kiotói kislánytól levelet és csomagot kapott. A csomagban egy kiri doboz lapult, benne pedig egy kimonós baba. A küldeményhez tartozó levél egy kérés volt: „Nagyon szeretnék elutazni a bácsival, de ha elvinne, se mehetnék, mert azt mondják, hogy gyönge és törékeny vagyok. Itt küldöm azonban babámat, vigye őt magával világkörüli útjára - helyettem. Gondolja azt, hogy a baba én vagyok. Majd ha visszatérnek, a babát legyen szíves visszaküldeni, mert az képes még rólam megfeledkezni és a bácsinál maradni" (Dzsúicsiró, 1929. 120. o.).

Szaidzsó Jaszo a kérésnek eleget téve bőröndjébe tette a babát, és utazásai során mindenhová magával vitte. Két év múltán visszatért Japánba, és nyomban levelet írt a baba tulajdonosának. Azonban nem érkezett válasz, a kislány nem érdeklődött játéka után. Talán rossz a cím - gondolta Szaidzsó Jaszo, és újra elolvasta a levelet. A cím helyes volt, azonban egy mondat belehasított a költő szívébe: „[...] ha elvinne, se mehetnék, mert azt mondják, hogy gyönge és törékeny vagyok [... ]" (Dzsúicsiró, 1929. 120. o.). Vagyis a játék baba időközben árva lett. Kis gazdája nem véletlenül küldte maga helyett a nagy útra, hiszen tudta, hogy ő maga nem vállalkozhat ilyen utazásra.

A történet jól tükrözi azt az emberi létünkből fakadó szemléletet, melyben a játék baba behelyettesített személyként jelenik meg. Ez a gondolat talán időben olyan távoli eseményekre vezethető vissza, ahol a mágikus cselekmény társított aktív jelentésértéket az emberszerú figuráknak. Először hasznosnak kellett lenniük, mint védelmezők, kísérők, segítők, hogy aztán a mindennapi élet részévé válhassanak.

\section{ÖsSZEGZÉs}

A tanulmányban bemutatott néhány kép és idézett szöveg a teljesség igénye nélkül, de igyekezett ráirányítani a figyelmet arra a tényre, hogy a vizuális hordozók jóval többek, mint illusztrációk, segédanyagok. Egy kép máshogyan szól és szólít meg, mint az írott dokumentum, ezért a felületes recepción túl a mélyebb jelentéstartalmak, összefüggések felfejtése széles kontextust tárhat fel, és kvázi szövegként járulhat hozzá a japán gyermekkép kutatásához.

\section{FELHASZNÁLT IRODALOM}

Bacon, A. M. (1891): Japanese Women and Girls. Mifflin and Company, Boston.

\footnotetext{
15 Imaoka Dzsúicsiró (1888-1973) tanulni érkezett Európába, 1922 és 1931 között Magyarországon élt, a magyar nyelvet és kultúrát tanulmányozta, ugyanakkor népszerúsítő előadásokkal, Japánról írt cikkeivel az első japán volt, kinek neve ismertté vált a magyar társadalomban (Umemura, 2006. 25. o.). Kultúraközvetítő tevékenységén keresztül a nagyközönség helyesebb képet alkothatott a távoli Japánról. Első magyar nyelvú könyve - az évek során írt cikkeinek tulajdonképpeni összefoglalója Új Nippon címmel 1929-ben jelent meg, benne számos, a jelen kutatás számára érdekes információval.
} 
Benedict, R. (1954): The Chrysanthemum and the Sword. Patterns of Japanese Culture. Tuttle Publishing, Boston, Rutland, Vermont, Tokyo.

Bozóky Dezső (1911): Két év Keletázsiában. Japán. Saját kiadás.

Buda Attila (2010, szerk.): Messziről felmeriülo, vonzó szigetek I. Japánról szóló, magyar nyelvü ismertetések a kezdetektől 1869-ig. Ráció Kiadó, Budapest.

Davis, F. H. (1913/1992): Myths and Legends of Japan. Dover Publications, Inc., New York.

Fajcsák Györgyi (2009): Kinai mügyüjtés Magyarországon a 19. század elejétől 1945-ig. Hopp Ferenc Kelet-Ázsiai Múvészeti Múzeum Kiskönyvtára 1., Budapest.

Ferenczy Mária és Kincses Károly (1999): Mandarin öszvérháton. Hopp Ferenc fényképei. Magyar Fotográfiai Múzeum - Hopp Ferenc Kelet-Ázsiai Mûvészeti Múzeum, Budapest.

Ferenczy Mária (2008): Hopp Ferenc életpályája. In: Fajcsák Györgyi és Renner Zsuzsanna (szerk.): A Buitenzorg-villa lakója. A világutazó, mügyüjtó Hopp Ferenc (1833-1919). Hopp Ferenc Kelet-Ázsiai Múvészeti Múzeum, Budapest. 51-59.

Frédéric, L. (1974): Japán hétköznapjai a szamurájok korában 1185-1603. Gondolat Kiadó, Budapest.

Hársvölgyi Virág (2018): „Pillanatfelvételek egy világkörüli sétáról”. Adalékok Kertész K. Róbert japán tanulmányútjához. In: Boreczky Ágnes és Vincze Beatrix (szerk.): Reformpedagógia és életreform - recepciós tendenciák, intézményesülési folyamatok. Neveléstudomány-történeti tanulmányok. Gondolat Kiadó, Budapest. 135-157.

Hathalmi Gabnay Ferenc (1901): Egy hazai játékbaba gyứjtemény. Néprajzi Értesito", 2. évf. 2. sz. 17-24.

Hearn, L. (1976/2009): Glimpses of unfamiliar Japan. Tuttle Publishing, Tokyo, Ruthland, Vermont, Singapore.

Imaoka Dzsúicsiró (1929): Új Nippon. Athenaeum, Budapest.

Japanese Art Abroad Research Project (1995, szerk.): Catalogue of Japanese Art in the Ferenc Hopp Museum of Eastern Asiatic Arts. Report of Japanese Art Abroad Research Project Vol. 5, Nichibunken Japanese Studies Series 6., Kyoto, Japan.

Németh András (2011): Emberi idővilágok - pedagógiai megközelitések. Gondolat Kiadó, Budapest.

Papp Melinda (2013): A korai gyermekkor rítusai Japánban és a hozzákapcsolódó hagyományos népi hitvilág. In: Hamar Imre (szerk.): Távol-Keleti tanulmányok. 3. 2011/1-2. sz. 227-248.

Pate, A.S. (2008): Japanese dolls. The fascinating world of ningyō. Tuttle Publishing, Tokyo; Rutland, Vermont; Singapore.

Romanowicz, B. (2017): Onna. Exhibition at the National Museum in Krakow. Februar - May 2017. Kraków. 
Pedagógiatörténeti Szemle • 5. évf. 1-2. sz. 45-56. o. • 2019

DOI:10.22309/PTSZEMLE.2019.1.3

Shimokava, K. (2002): Kindai Meiji, Taishō-hen - Kodomo-shi nenhyō. Kawade shobō shinsha, Tokyo.

Takeguchi, M. (2002): Sode ichimatsu dolls. Daruma Magazine, 26. 48-52.

Umemura, Y. (2006): A japán-tengertől a Duna-partig. Imaoka Dzsúicsiró életpályája a magyar-japán kapcsolatok tükrében. Gondolat Kiadó, Budapest.

Wulf, Ch. (2007): Az antropológia rövid összefoglalása. Enciklopédia Kiadó, Budapest. 